\title{
Vulnerability to Human Immunodeficiency Virus infection among women of childbearing age
}

\author{
Vulnerabilidade à infecção pelo Vírus da Imunodeficiência Humana entre mulheres em \\ idade fértil
}

Ana Clara Patriota Chaves ${ }^{1}$, Carla Suellen Pires de Sousa ${ }^{1}$, Paulo César de Almeida ${ }^{1}$, Elys Oliveira Bezerra ${ }^{1}$, George Jó Bezerra Sousa ${ }^{1}$, Maria Lúcia Duarte Pereira ${ }^{1}$

Objective: to analyze female vulnerability factors associated with human immunodeficiency virus infection among women of childbearing age. Methods: a case-control epidemiological study with women of childbearing age performed at a referral service center. Data on socioeconomic vulnerability, individual, partners and health services were collected. These were analyzed in univariate, bivariate and multivariate ways. Results: 174 women participated in the study, in which it was shown that the chances for infection increased fourfold to those with family income up to 1,000.00, 5.5 times more for those who did not know female condoms, 16.7 times more for those who used alcohol and 4.8 times higher for those who did not receive guidelines in the health services. Conclusion: the analysis made it possible to identify the main vulnerability markers for virus infection in women of childbearing age, especially those of an individual, socioeconomic and programmatic nature.

Descriptors: Sexually Transmitted Diseases; HIV; Acquired Immunodeficiency Syndrome; Women's Health; Health Vulnerability.

Objetivo: analisar fatores de vulnerabilidade feminina associados à infecção pelo Vírus da Imunodeficiência Humana entre mulheres em idade fértil. Métodos: estudo epidemiológico do tipo caso-controle com mulheres em idade fértil realizado em um serviço de referência. Foram coletados dados sobre vulnerabilidade socioeconômicos, individuais, dos parceiros e dos serviços de saúde. Estes foram analisados de forma uni, bi e multivariada. Resultados: fizeram parte da pesquisa 174 mulheres, na qual se evidenciou que as chances para infecção aumentavam quatro vezes para as que tinham renda familiar até 1.000,00, 5,5 vezes mais para aquelas que não conheciam camisinha feminina, 16,7 vezes mais para as que fizeram uso de bebida alcoólica e 4,8 vezes maior para aquelas que não recebiam orientações nos serviços de saúde. Conclusão: a análise permitiu identificar os principais marcadores de vulnerabilidade para a infecção do vírus em mulheres em idade fértil, principalmente os de cunho individual, socioeconômico e programático.

Descritores: Doenças Sexualmente Transmissíveis; HIV; Síndrome de Imunodeficiência Adquirida; Saúde da Mulher; Vulnerabilidade em Saúde.

\footnotetext{
${ }^{1}$ Universidade Estadual do Ceará. Fortaleza, CE, Brazil. 


\section{Introduction}

In recent years, the rate of detection of Human Immunodeficiency Virus (HIV) in pregnant women in Brazil has been increasing. In 2007, the rate was 2.3 cases/1000 live births and in 2017 increased to 2.8/1000 live births, an increase of $21.7 \%$. This tendency has also been observed in all Brazilian regions, with the exception of the Southeast. Considering that the highest rates of increase occurred in the North (118.5\%) and Northeast (87.5\%). In this scenario, the South region is also notable for the increase in detection rate twice as high as the national level ${ }^{(1)}$.

The process of feminization of the Acquired Immunodeficiency Syndrome (AIDS) epidemic in Brazil is of concern to public health because of increased perinatal morbidity and mortality, decreased fertility and increased cases of vertical transmission, thus increasing the number of infected individuals with $\operatorname{HIV}^{(2)}$. To minimize such consequences, it is therefore necessary to take into account the fact that women constitute a group that is vulnerable to Sexually Transmissible Infections (STIs) and should be adequately assisted.

In this context, the concept of vulnerability(3) refers to the susceptibility of individuals and populations to injuries or risks, exposure to damage resulting from aspects that, although presented as individual, re-position the individual in relation to the collective. The dimensions of vulnerability encompass individual, social, and programmatic factors. Awareness of STI/HIV/AIDS and prevention among women is therefore influenced by biological, psychological, social, economic, cultural and religious factors, as well as the perception of the partner and the dynamics of health services, all these are determinants of greater or lesser vulnerability ${ }^{(4)}$.

In addition, many women who maintain an inferior relationship with the partner usually have low power of choice in their love relationships and difficulty negotiating with the partner regarding prevention, thus increasing their risk situation. They believe that because they are in a stable, trustworthy, faithful and monogamous relationship there is no risk of contracting STI/HIV/AIDS ${ }^{(5-6)}$. Thus, the use of condoms is considerably reduced. The dialogue between the couple on the use of condoms generates an assumption of infidelity, and is often seen as a taboo or a stigma for the prevention of these diseases, making it harder to use sexual intercourse ${ }^{(7-8)}$.

Vulnerability can also be perceived by the degree of access to health services, their quality, the integrated network of care and the difficulty of health services in the prevention care that direct the actions to the individual, not to the couple. Another point to be highlighted is the lack of specialized care for the patient under such conditions, especially involving the affective sexual life ${ }^{(9)}$.

It is observed that several risk factors and vulnerability among women can influence the prevention of STI/HIV/AIDS. Thus, investigations that deal with risk factors and vulnerabilities, especially in the field of these diseases, present themselves as powerful resources to work the social differences in the distribution of illness and its determinants. Thus, this study aimed to analyze factors of female vulnerability associated with Human Immunodeficiency Virus infection among women of childbearing age.

\section{Methods}

Epidemiological study of the case-control type, conducted in January 2014 in two referral outpatient clinics to care for people with infectious diseases. The first, in a hospital linked to the State Health Network of the State of Ceará and the second, in a basic health unit linked to the Municipal Health Department of Fortaleza/CE, Brazil. Both services are located in the same territory and are part of the Regional Executive Secretariat III of the capital of Ceará.

In order to compose the case group, women aged between 18 and 49 years old, who were diagnosed with HIV/AIDS, were cared for or followed up at the IST/HIV/AIDS outpatient clinic, resided in Fortaleza and showed availability for the study. To be part 
of the control group, women should be between 18 and 49 years of age, not have a positive diagnosis of STI/HIV/AIDS, begin their sexual life, be accompanied at the Basic Health Unit, reside in Fortaleza and be willing to participate in the study. For both groups, pregnant women and those who for some reason were not able to respond to the research, such as visual, hearing or any physical weakness were excluded.

Considering that in the year of data collection, there were 1,304,297 women residing in the city and of these, 868,117 of fertile age ( $65 \%$ of the total), this percentage was used in the calculation of the sample. The average of the population found in care in both services was 300 women of childbearing age in the period of collection.

Sampling was performed to delimit a significant sample. A confidence interval of $95 \%(\mathrm{z}=1.96)$, a permissible error of $5 \%$, test power of $80 \%$, and proportion of people exposed to the risk factor in the general population of $50.0 \%$ were set. Thus, a sample of 87 women should be obtained for the case group and 87 for the control group, totaling 174 women.

Participants were selected using the non-probabilistic sampling technique. In the case group selection, the women who were in follow-up consultation at the STI/HIV/AIDS outpatient clinic of the referral hospital in the municipality (first outpatient clinic) were approached. The selection of the control group was based on the approach of women who were waiting in the gynecological prevention service in primary care (second ambulatory). After explaining the research, we selected those that were compatible with the inclusion criteria and that accepted to participate in the research, reducing the selection bias.

The data were collected through a structured form, created by the authors, with closed questions (dichotomous or with the possibility of more than one answer) that addressed questions about sociodemographic aspects, sexuality and sexual behavior, social and affective relations, as well as used. As variables, were considered those on individual vulnerability, relationship with the partner, socioeconomic vulnerabi- lity and programmatic vulnerability.

Data relating to the form were processed in the statistical software Statistical Package for Social Sciences 16.0. The analysis of these data involved simple descriptive statistics, using the measures of central tendency, dispersion, simple and relative frequency for the description of the results. The association between categorical variables was also performed using the chi-square test, with a significance level of less than $5 \%(\mathrm{p}<0.05)$.

For the multivariate analysis of logistic regression, the variables that had a value of $p<0.200$ in the initial model were used. After the first analysis, only those with $\mathrm{p}<0.100$ were considered. In the final mo$\mathrm{del}$, the variables that presented a $\mathrm{p}<0.05$ were considered significant. For the interpretation of the data, the Odds Ratio (OR) value with its respective Confidence Intervals of $95 \%$ (95\% CI) was also considered for interpretation of the results.

The project was conducted in accordance with the principles of bioethics in accordance with resolution 466/12 and approved by the Research Ethics Committee of the State University of Ceará under opinion 466.772 and Certificate of Presentation for Ethical Appreciation in 12103513.1.0000.5534. All the participants signed the Free and Informed Consent Term, which explained the risks and benefits of the research, including the science about the withdrawal of participation in the research at any time they thought pertinent.

\section{Results}

The 174 women found in the sample calculation were part of the study, but due to the difficulty of finding those with characteristics that met the criteria of the research, 84 were allocated in the case group and 90 in the control group. Table 1 shows the distribution of the same according to their socioeconomic characteristics (some variables suffered losses).

It was observed that the case group had a large proportion, 34 (40.5\%) of the women aged 31-40 ye- 
ars (mean 36 years). They studied on average 7.4 years and many of them were in stable union. The average family income was R \$ 800.00,55 of them (65.5\%) did not work, but said they received benefits from the government, mainly Bolsa Família (government grant). The control group had the most frequent age group, between 18-30 years (average of 32 years), with 10 years of study and married. The average family income was approximately R \$1,400.00, 48 (53.3\%) women worked and 52 (58.4\%) did not receive benefits from the government. Among those who received, the most prevalent was Bolsa Família.

Table 1 - Distribution of socioeconomic variables of women with HIV (cases) and without (controls)

\begin{tabular}{lcc}
\hline Variables & Cases & Controls \\
\cline { 2 - 3 } & $\mathbf{n ~ ( \% )}$ & $\mathbf{n}(\%)$ \\
\hline Age (years) & & \\
$18-30$ & $22(26.2)$ & $45(50.0)$ \\
$31-40$ & $34(40.5)$ & $23(25.6)$ \\
$41-49$ & $28(33.3)$ & $22(24.4)$ \\
Years of study (years) & & \\
$0-7$ & $37(44.6)$ & $17(21.0)$ \\
$>7$ & $46(55.4)$ & $64(79.0)$ \\
Marital status & & \\
Single & $24(28.6)$ & $29(32.2)$ \\
Married & $12(14.3)$ & $32(35.6)$ \\
Stable union & $39(46.4)$ & $21(23.3)$ \\
Separated & $7(8.3)$ & $6(6.7)$ \\
$\quad$ Widow & $2(2.4)$ & $2(2.2)$ \\
Works & & \\
No & $55(65.5)$ & $42(46.7)$ \\
Yes & $29(35.5)$ & $48(53.3)$ \\
Family income (reais) & & \\
to 1.000,00 & $57(72.2)$ & $41(51.2)$ \\
$>1.000,00$ & $22(27.8)$ & $39(48.8)$ \\
Receives government benefits & & \\
Yes & $60(71.4)$ & $37(41.6)$ \\
No & $24(28.6)$ & $52(58.4)$ \\
\hline
\end{tabular}

Table 2 presents factors that refer to the risk and vulnerability to STI/HIV/AIDS among the sample of 174 women divided into case and control groups. Regarding the individual vulnerability, $54.8 \%$ of the cases and $62.9 \%$ of the controls started the sexual life above 15 years of age with an average of 16 years for the first sexual intercourse in both groups. Among women with a positive diagnosis, 59 (70.2\%) did not use a condom at the first sexual intercourse. Only 32 (38.1\%) stated that they had anal-type relationships before knowing their diagnosis. Most of them did not know the female condom. It is worth mentioning that, regarding economic vulnerability, 14 (16.7\%) of the cases offered sexual relations for benefits against only two $(2.2 \%)$ women in the control group. Regarding program vulnerability, the lack of guidelines on STI/ AIDS and condoms was about twice as high in cases.

In the final logistic regression model (Table 3), it was observed that family income up to $R \$$ $1,000.00(p=0.009)$, non-knowledge of female condom ( $p=0.002)$, alcohol consumption 0.001), lack of communication with the partner about sex $(p=0.001)$ and lack of STI/AIDS guidelines $(\mathrm{p}=0.002)$ significantly contributed to the increased risk of STI/HIV/ AIDS in women of childbearing age. It is important to emphasize that, for the adjusted odds ratio (AOR) of this model, the use of alcoholic beverages increased by 16 times the odds for STI/HIV/AIDS in these women, followed by the lack of dialogue with the partner $(A O R=6,1)$, lack of knowledge of female condom $(\mathrm{AOR}=5.5)$ and lack of guidelines $(\mathrm{AOR}=4.8)$. 
Table 2 - Distribution of risk factors for women with HIV (cases) and without (controls)

\begin{tabular}{|c|c|c|c|c|c|}
\hline \multirow{2}{*}{ Variables } & \multirow{2}{*}{$\begin{array}{l}\text { Cases } \\
\text { n (\%) }\end{array}$} & \multirow{2}{*}{$\begin{array}{c}\text { Controls } \\
\text { n (\%) }\end{array}$} & \multirow{2}{*}{$\begin{array}{l}\text { Odds } \\
\text { Ratio }\end{array}$} & \multirow{2}{*}{ CI95\%* } & \multirow{2}{*}{$\mathbf{p}$} \\
\hline & & & & & \\
\hline \multicolumn{6}{|l|}{ Individual vulnerability } \\
\hline Sexual intercourse between nine and 15 years & $38(45.2)$ & $33(37.1)$ & 1.4 & $(0.7-2.6)$ & 0.300 \\
\hline No condom at first sexual intercourse & $59(70.2)$ & $48(53.3)$ & 2.0 & $(1.1-3.8)$ & 0.020 \\
\hline Inconsistent condom use & $71(84.5)$ & $71(78.9)$ & 1.5 & $(0.7-3.1)$ & 0.300 \\
\hline Sexual intercourse & $32(38.1)$ & $30(33.3)$ & 1.3 & $(0.6-2.2)$ & 0.500 \\
\hline Inconsistency of condom in anal intercourse & $23(71.8)$ & $21(70.0)$ & 1.1 & $(0.3-3.2)$ & 0.800 \\
\hline Non-knowledge of female condom & $57(67.9)$ & $43(47.8)$ & 2.2 & $(1.2-4.2)$ & 0.007 \\
\hline Use of alcoholic beverage & $38(45.8)$ & $9(10.0)$ & 7.6 & $(3.3-17.1)$ & $<0.001$ \\
\hline Use of illicit drugs & $19(22.6)$ & $11(12.5)$ & 2.0 & $(0.9-4.6)$ & 0.080 \\
\hline Symptoms of vaginal sores & $24(28.6)$ & $11(12.2)$ & 2.8 & $(1.3-6.3)$ & 0.007 \\
\hline Symptoms of anal sore & $13(15.5)$ & $2(2.2)$ & 8.0 & $(1.7-36.8)$ & 0.002 \\
\hline \multicolumn{6}{|l|}{ Relationship with partner } \\
\hline Suffered partner violence & $31(36.9)$ & $12(13.5)$ & 3.7 & $(1.7-7.9)$ & $<0.001$ \\
\hline Alcohol user partner & $78(92.9)$ & $63(70.8)$ & 5.3 & $(2.1-13.8)$ & $<0.001$ \\
\hline Drug user partner & $40(47.6)$ & $20(22.5)$ & 3.2 & $(1.6-6.0)$ & 0.001 \\
\hline Inconsistent dialogue about sexual intercourse & $65(77.4)$ & $40(44.4)$ & 4.3 & $(2.2-8.6)$ & $<0.001$ \\
\hline Condom confidence and inconsistency & $72(85.7)$ & $63(70.0)$ & 2.6 & $(1.2-5.5)$ & 0.010 \\
\hline \multicolumn{6}{|l|}{ Socioeconomic vulnerability } \\
\hline Up to seven years of study & $37(44.6)$ & $17(21.0)$ & 3.0 & $(1.5-6.0)$ & 0.001 \\
\hline Family income up to $\mathrm{R} \$ 1,000.00$ & $57(72.2)$ & $41(51.2)$ & 2.5 & $(1.2-4.7)$ & 0.007 \\
\hline Unemployed & $55(65.5)$ & $42(46.7)$ & 2.1 & $(1.1-4.0)$ & 0.010 \\
\hline Sexual intercourse for benefits & $14(16.7)$ & $2(2.2)$ & 8.8 & $(1.9-40.0)$ & 0.001 \\
\hline \multicolumn{6}{|l|}{ Programmatic vulnerability } \\
\hline \multicolumn{6}{|l|}{ There is no guidance on: } \\
\hline Sexually Transmitted Infection/Acquired Immunodeficiency Syndrome & $56(66.7)$ & $25(28.1)$ & 5.1 & $(2.6-9.7)$ & $<0.001$ \\
\hline Condom & $40(47.6)$ & $29(32.6)$ & 1.8 & $(1.0-3.4)$ & 0.040 \\
\hline $\begin{array}{l}\text { Sexually Transmitted Infection/Acquired Immunodeficiency Syndrome in } \\
\text { gynecological consultation }\end{array}$ & $51(60.7)$ & $32(36.8)$ & 2.7 & $(1.4-4.9)$ & 0.002 \\
\hline
\end{tabular}

Table 3 - Multivariate analysis of socio-demographic characteristics and risk factors for STI/HIV/AIDS

\begin{tabular}{|c|c|c|c|c|c|c|}
\hline \multirow{2}{*}{ Variables } & Cases & Controls & \multirow{2}{*}{ GOR $^{*}$} & \multirow{2}{*}{$\mathbf{A O R}^{\dagger}$} & \multirow{2}{*}{ CI95\% ${ }^{\ddagger}$} & \multirow{2}{*}{$\mathbf{p}$} \\
\hline & n (\%) & n (\%) & & & & \\
\hline \multicolumn{7}{|c|}{ Family income (R\$) } \\
\hline To $\mathrm{R} \$ 1.000,00$ & $57(72.2)$ & $41(51.2)$ & 2.5 & 4.0 & $(1.4-11.5)$ & 0.009 \\
\hline$>1.000,00$ & $22(27.8)$ & $39(48.8)$ & 1.0 & 10 & & \\
\hline \multicolumn{7}{|c|}{ Know the female condom } \\
\hline No & $57(67.9)$ & $43(47.8)$ & 2.2 & 5.5 & $(1.8-16.4)$ & 0.002 \\
\hline Yes & $27(32.1)$ & $47(52.2)$ & 1.0 & 1.0 & & \\
\hline \multicolumn{7}{|c|}{ Use of alcoholic beverage } \\
\hline Yes & $38(45.8)$ & $9(10.0)$ & 7.6 & 16.7 & $(4.7-59.2)$ & $<0.001$ \\
\hline No & $45(54.2)$ & $81(90.0)$ & 1.0 & 1.0 & & \\
\hline \multicolumn{7}{|c|}{ Dialogue with partner about sex } \\
\hline No & $65(77.4)$ & $40(44.4)$ & 4.3 & 6.1 & $(2.1-17.4)$ & 0.001 \\
\hline Yes & $19(22.6)$ & $50(55.6)$ & 1.0 & 1.0 & & \\
\hline \multicolumn{7}{|c|}{$\begin{array}{l}\text { Guidance on Sexually Transmitted Infections/Acquired Immu- } \\
\text { nodeficiency Syndrome in health services }{ }^{\S}\end{array}$} \\
\hline No & $56(66.7)$ & $25(28.1)$ & 5.1 & 4.8 & $(1.7-13.0)$ & 0.002 \\
\hline Yes & $28(33.3)$ & $64(71.9)$ & 1.0 & 1.0 & & \\
\hline
\end{tabular}




\section{Discussion}

Among the limitations of the study, we can mention the composition of the sample, sampling technique, as well as some data lost and the restriction of the data to the quantitative form. Even so, the findings become important in understanding the aspects that may involve female vulnerability to sexually transmitted infections.

In this research it was possible to verify that the inconsistency of condom use is common in women of childbearing age. This study points to the fixed partnership as a resistance factor for non-use of the condom, revealing vulnerability to STI/HIV/AIDS ${ }^{(10)}$. However, the inconsistency in the use of the fixed partner method is not restricted to the Brazilian population; it is also a worldwide concern. During individual interviews with 1,357 African-American adults, consistent condom use was reported by $56.0 \%$ of participants who had casual partners and $23.0 \%$ of those with fixed partners ${ }^{(11)}$. Such risky sexual behavior among fixed partners can have many causes, from the negative attitude of the partner to the condom such as the association of the use of the method with lack of confidence.

The female condom is not yet widely known or known by women. In the control group, the fact that they did not know the female condom led to a twofold higher chance of contracting HIV. This fact was verified by a study in the State of Paraíba, Brazil, where, through the application of the knowledge, attitudes and practices survey, it was possible to observe only one occurrence of adequate practice ${ }^{(12)}$.

In this way, the use of female condoms demonstrates the knowledge of the body and health, guaranteeing confidence and empowerment for these women $^{(13)}$. Specific characteristics of this type of condom, such as its use, lubrication and correct positioning, are still scarce among the female group ${ }^{(14)}$.

In addition, alcohol is indicated as a factor responsible for the decrease in critical capacity, leading people to behave differently from when they are sober, especially significantly increasing inconsistent condom use, which may favor unprotected sexual intercourse and IST transmission ${ }^{(15)}$. In addition to the known deleterious effects of alcoholism and its influence on HIV incidence, the literature still emphasizes other mechanisms resulting from the combination of both, including immunological senescence, inflammation and hyper coagulation ${ }^{(16)}$.

In addition to alcohol, concomitant use of multiple substances is associated with sexual risk and high rates of HIV infection. Corroborating this finding, a systematic review study with meta-analysis showed that the risk of contracting HIV increased 3.5-fold for cocaine use, 2.7-fold for amphetamine use, 3.3-fold for opioids and stimulants, 2.1 fold for opioids and sedatives and 2.0 times for heroin ${ }^{(17)}$.

This research found that lack of dialogue with partner contributes to HIV infection. Accordingly, research indicates that when exposed to abusive relationships, female adolescents are more likely to have inconsistent condom use or not to use it during sex. This type of relationship increases the chances of these women testing positive for HIV or other STIs ${ }^{(18)}$. If they become pregnant, these women are still seen under the discriminatory views of the health team, treating them as being solely responsible for the fact ${ }^{(19)}$.

The vulnerability of the subject or the group reveals inequalities in access to quality and comprehensive care related to health promotion. Educational practices that promote integral care are essential ways to contain the HIV epidemic, since sexual behavior cannot be isolated from broader social, economic and cultural influences that guide the life of the individual. In this context, it is important that actions encompassing health promotion programs be effective in reducing such vulnerability.

\section{Conclusion}

The present study made it possible to identify the vulnerability markers for STI/HIV/AIDS, especially low income, lack of knowledge about female 
condoms, frequent use of alcohol, lack of dialogue with the partner about sex, and lack of guidance on such infections. They point out fragilities in the network of care for women of childbearing age, as well as structural deficiencies in support of this woman. Thus, the establishment of these factors as a priority during the care of this public may be fundamental for breaking the chain of transmission of the disease.

\section{Acknowledgments}

To the Coordenação de Aperfeiçoamento de Pessoal de Nível Superior.

\section{Collaborations}

Chaves ACP and Pereira MLD contributed to the design. Almeida PC contributed with the analysis and interpretation of the data. Sousa CSP, Bezerra EO and Sousa GJB contributed with the essay writing and critical review of the intellectual content. All authors collaborated with the final approval of the version to be published.

\section{References}

1. Ministério da Saúde (BR). Secretaria de Vigilância em Saúde, Departamento de DST, Aids e Hepatites Virais. Boletim Epidemiológico HIV/AIDS 2018 [Internet]. 2018 [citado 2019 mar 18]. Disponível em:http://www.aids.gov.br/pt-br/pub/2018/ boletim-epidemiologico-hivaids-2018

2. Bick MA, Ferreira T, Sampaio CO, Padoin SMM, Paula CC. Profile of infected pregnant women and children exposed to HIV at a specialized service in the South of Brazil. Rev Bras Saúde Mater Infant. 2018; 18(4):791-801. doi: http://dx.doi. org/10.1590/1806-93042018000400007

3. Sevalho G. The concept of vulnerability and health education based on the theory laid out by Paulo Freire. Interface. 2018;22(64):177-88. doi: http:// dx.doi.org/10.1590/1807-57622016.0822
4. Duarte MTC, Parada CMGL, Souza LR. Vulnerability of women living with HIV/aids. Rev Latino-am Enfermagem. 2014; 22(1):68-75. doi: http:// dx.doi.org/10.1590/0104-1169.2837.2377

5. Silva WS, Oliveira FJF, Serra MAAO, Rosa CRAA, Ferreira AGN. Factors associated with condom use in people living with HIV/AIDS. Acta Paul Enferm. 2015; 28(6):587-92. doi: http://dx.doi. org/10.1590/1982-0194201500096

6. Harder VS, Ayer LA, Rose GL, Naylor MR, Helzer JE. Alcohol, moods and male-female differences: daily interactive voice response over 6 months. Alcohol Alcohol. 2014; 49(1):60-5. doi: http:// dx.doi.org/10.1093/alcalc/agt069

7. Valim EMA, Dias FA, Simon CP, Almeida DV, Rodrigues MLP. Condom use among adolescents in public schools oh the city of state of Minas Gerais, Brazil: knowledge and atittudes. Cad Saúde Coletiva. 2015; 23(1):44-9. doi: http:// dx.doi.org/10.1590/1414-462X201500010008

8. Reis RK, Melo ES, Gir E. Factors associated with inconsistent condom use among people living with HIV/Aids. Rev Bras Enferm. 2016; 69(1):40-6. doi: dx.doi.org/10.1590/0034-7167.2016690106i

9. Maliska ICA, Padilha MI, Andrade SR. Policies directed towards STD/AIDS and their politicalcare integration in the context of the SUS: a study of the city of Florianópolis, SC, Brazil. Texto Contexto Enferm. 2014; 23(3):639-47. doi: http://dx.doi. org/10.1590/0104-07072014003290012

10. Santos CMA, Oliveira JDS, Lima SVM, Santos AD, Góes MA, Sousa LB. Men's knowledge, attitudes and practice regarding sexually transmitted diseases. Cogitare Enferm. 2018; 23(1):e54101. doi: http://dx.doi.org/10.5380/ce.v23i1.54101

11. Nehl EJ, Elifson K, DePadilla L, Sterk C. Sex partner type, drug use and condom use self-efficacy among African Americans from disadvantaged neighborhoods: are associations with consistent condom use moderated by gender? J Sex Res. 2016; 53(7):805-15. doi: http://dx.doi.org/10.10 80/00224499.2015.1092018 
12. Andrade SSC, Zaccara AAL, Leite KNS, Brito KKG, Soares MJGO, Costa MML, et al. Knowledge, attitude and practice of condom use by women of an impoverished urban area. Rev Esc Enferm USP. 2015; 49(3):364-71. doi: dx.doi.org/10.1590/ S0080-623420150000300002

13. Penna LHG, Ribeiro LV, Ramos KAA, Félix FO, Guedes CR. Empowerment of female adolescents at shelters: sexual health terms of the Theoretical Model of Nola Pender. Rev Enferm UERJ. 2016; 24(5):e27403. doi: https://dx.doi.org/10.12957/ reuerj.2016.27403

14. Andrade SSC, Zacçara AAL, Leite KNS, Nunes MLA, Coêlho HFC, Oliveira SHS. Male and female condoms: what to women of a subnormal agglomerate know. Invest Educ Enferm. 2016; 34(2):271-9. doi: http://dx.doi.org/10.17533/ udea.iee.v34n2a06

15. Wendland EM, Horvath JDC, Kops NL, Bessel M, Caierão J, Hohenberger GF, et al. Sexual behavior across the transition to adulthood and sexually transmitted infections: findings from the national survey of human papillomavirus prevalence (POPBrazil). Medicine. 2018; 97(33):e11758. doi: dx.doi.org/10.1097\%2FMD.0000000000011758
16. Williams EC, Hahn JA, Saitz R, Bryant K, Lira MC, Samet JH. Alcohol use and Human Immunodeficiency Virus (HIV) infection: current knowledge, implications, and future directions. Alcohol Clin Exp Res. 2016; 40(10):2056-72. doi: http://dx.doi.org/10.1111/acer.13204

17. Tavitian-Exley I, Vickerman P, Bastos FI, Boily MC. Influence of different drugs on HIV risk in people who inject: systematic review and meta-analysis. Addiction. 2015; 110(4):572-84. doi: https://doi. org/10.1111/add.12846

18. Pettifor A, Stoner M, Pike C, Bekker L. Adolescent lives matter: preventing HIV in adolescents. Curr Opin HIV AIDS. 2018; 13(3):265-73. doi: https:// dx.doi.org/10.1097\%2FCOH.0000000000000453

19. Caldas MAG, Porangaba SCF, Melo ES, Gir E, Reis RK. Perception of the nursing team on pregnancy concerning infection caused by HIV. Rev Rene. 2015; 16(1):29-37. doi: https://dx.doi. org/10.15253/2175-6783.2015000100005 